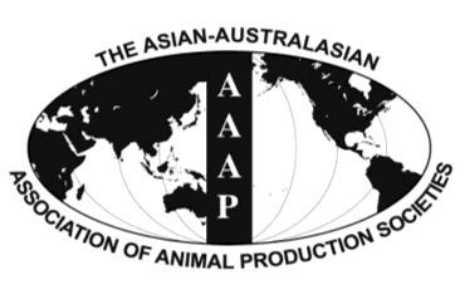

Open Access

Asian Australas. J. Anim. Sci.

Vol. 28, No. 10 : 1454-1464 October 2015

http://dx.doi.org/10.5713/ajas.15.0085

www.ajas.info

pISSN 1011-2367 elSSN 1976-5517

\title{
Measurement of the Intestinal Digestibility of Rumen Undegraded Protein Using Different Methods and Correlation Analysis
}

\author{
Y. Wang ${ }^{1,2, *}$, Y. G. Zhang ${ }^{2}$, , Xiaolan Liu ${ }^{1}$, N. K. Kopparapu ${ }^{1}$, Hangshu Xin ${ }^{2}$, J. Liu ${ }^{1}$, and Jianhua Guo ${ }^{1}$ \\ ${ }^{1}$ College of Food and Biological Engineering, Qiqihar University, Qiqihar 161006, China
}

\begin{abstract}
Four methods were adopted, including the mobile nylon bag (MNB) method, modified three-step in vitro (MTS) method, original three-step in vitro (OTS) method, and acid detergent insoluble nitrogen (ADIN) estimating method, to evaluate the intestinal digestibility of rumen undegradable protein (DRUP) of 10 types of concentrates and 7 types of roughages. After correlation analysis to determine the DRUP values using the MNB, MTS, OTS, and ADIN methods, the study aimed to find out appropriate methods to replace the MNB method due to its disadvantages such as high price, long time period, and use of a duodenal T-fistula. Three dairy cows with a permanent ruminal fistula and duodenal T-fistula were used in a single-factor experimental design. The results showed that the determined DRUP values using the MNB method for soybean meal, cottonseed meal, rapeseed meal, sunflower meal, corn germ meal, corn, rice bran, barley, wheat bran, corn fiber feed, Alfalfa (Zhao dong), Alfalfa (Long mu 801), Alfalfa (Long mu 803), grass (North), Grass (Inner Mongolia), corn silage and corn straw were 98.13\%, 87.37\%, 88.47\%, 82.60\%, 75.40\%, 93.23\%, 69.27\%, 91.27\%, $72.37 \%, 79.03 \%, 66.72 \%, 68.64 \%, 73.57 \%, 50.47 \%, 51.52 \%, 54.05 \%$, and $43.84 \%$, respectively. The coefficient of determination $\left(R^{2}=\right.$ $0.964)$ of the results between the MTS method and the MNB method was higher than that $\left(R^{2}=0.942\right)$ between the OTS method and the MNB method. The coefficient of determination of the DRUP values of the concentrates among the in vitro method (including the MTS and OTS methods) and the MNB method was higher than that of the roughage. There was a weak correlation between the determined DRUP values in concentrates obtained from the ADIN method and those from the MNB method, and there was a significant correlation $(\mathrm{p}<0.01)$ between the determined DRUP values of the roughage obtained from the MNB method and those obtained from ADIN method. The DRUP values were significantly correlated with the nutritional ingredients of the feeds. The regression equation was DRUP $=100.5566+0.4169 \mathrm{CP}-0.4344 \mathrm{SP}-0.7102 \mathrm{NDF}-0.7950 \mathrm{EE}\left(R^{2}=0.8668, \mathrm{p}<0.01 ; \mathrm{CP}\right.$, crude protein; SP, soluble protein; NDF, neutral detergent fiber; EE, ether extract). It was concluded that both the MTS method and the OTS may suitable to replace the MNB method for determining the DRUP values and the former method was more effective. Only the ADIN method could be used to predict the values of the roughages but conventional nutritional ingredients were available for all of the samples' DRUP. (Key Words: Protein Supplement, Energy Feed, Rumen Undegraded Protein, Correlation Analysis, Intestinal Digestibility)
\end{abstract}

\section{INTRODUCTION}

The intestinal digestibility of rumen undegraded protein (DRUP) is one important parameter in the updated protein evaluation systems for ruminant production, and it affects

\footnotetext{
* Corresponding Authors: Y. Wang. Tel: +86-13604524702, Fax: +86-0452-2742731, E-mail: wangyan0468@126.com / Y. G. Zhang. Tel: +86-13945093196, Fax: +86-0452-2742731, E-mail: zhangyonggen@sina.com

${ }^{2}$ Animal Science and Technology Institute, Northeast Agriculture University, Harbin 150030, China.

Submitted Jan. 29, 2015; Revised Mar. 18, 2015; Accepted Apr. 16, 2015
}

the milk yield and productivity of dairy cows (Frydrych, 1992). Compared with a number of studies on rumen degradation rates of feeds, there is little information available on the intestinal digestibility of the rumen undegraded protein (RUP) of feeds, therefore the intestinal digestibility is usually considered to be a fixed value in most protein evaluation systems (Frydrych, 1992). Before the 2001 NRC version, the digestibility of the undegradable intake protein (UIP) of all feedstuffs was considered to be $80 \%$. In fact, the intestinal digestibility and amino acids profile of RUP vary widely among feedstuffs (Prestl $p k k e n$ and Rise, 2003). Due to the lack of available statistics, the 
protein evaluation system for beef (NRC, 1996) also adopts $80 \%$ as its UIP digestibility; however, the dairy NRC (2001) now uses various digestibility rates ranging from $50 \%$ to $100 \%$. The reasons for the change are the varieties, resources and processing methods for the concentrates, and florescence and harvesting time for the roughage (Kusumanti et al., 1996; Harstad and Prestlkken, 2000; Taghizadeh et al., 2005). Based on ruminal incubations for $16 \mathrm{~h}$, researchers report that the average DRUP value $(88.2 \%)$ of the concentrates was higher than that of forages (70.8\%) (Frydrynch, 1992). Negi et al. (1988) also showed the low intestinal digestibility of the roughages based on the DRUP values of $66 \%$ for alfalfa hay $(16.1 \%$ crude protein $[\mathrm{CP}])$, and $37.8 \%$ for the DRUP value of Eragrostis curvula hay $(5.7 \% \mathrm{CP})$. Obviously, there is no fixed value to replace the DRUP values for all the feeds. Currently, the methods for determining DRUP values mainly include the mobile nylon bag (MNB) method, the modified three-step in vitro (MTS) method, the original three step in vitro (OTS) method and the acid detergent insoluble nitrogen (ADIN) estimated method. Among them, the in situ mobile nylon bag (MNB) method is widely accepted, because it has many advantages, such as an effective recurrence rate and a significant correlation with the data obtained from the in vivo method, which is in agreement with De Boer et al. (1987), who reported that the MNB method is a routine method for determining the DRUP values

However, the MNB method is an invasive procedure that requires the animal to be fitted with ruminal, duodenal and sometimes ileal fistula. The procedure is also timeconsuming and currently there is no standardized protocol for conducting this procedure. Calsamiglia and Stern (1995) concluded that the three-step in vitro method can imitate an animal's physiological conditions, which saves much time and efforts. However, the pepsin (P-7012) used in the original three-step in vitro (OTS) method is expensive, and the trichloroacetate used in the OTS method may produce environmental pollution, and the small intestinal digestibility of undegradable rumen amino acids cannot be determined. Therefore, this method was further improved by Gargallo et al. (2006), who introduced MTS. In addition, the lesser intestinal digestibility of RUP can be predicted by the ADIN method, which was proposed by Webster et al. (1984), and the formulation was: DRUP $=0.90$ (RUP NADIN)/RUP of $\mathrm{N}$. This simple and convenient method is the most common one used to estimate the DRUP values. In this study, the DRUP values were determined by the MNB method, the OTS method, the MTS method and predicted by ADIN method. After that, correlation analysis was made to obtain DRUP values among the OTS, MTS, ADIN, and MNB methods to find out the best replacement for the MNB methods. This work aimed to determine the best replacement for the MNB method to obtain DRUP values.

\section{MATERIALS AND METHODS}

\section{Materials}

Five kinds of protein supplements including soybean meal (SBM), cotton seed meal (CSM), rapeseed meal (RSM), sunflower meal (SFM), corn germ meal (CGM), five kinds of energy feed including rice bran (RB), corn, barley, wheat bran (WB), corn fiber feed (CFF), and seven kinds roughages including alfalfa (Zhao dong), alfalfa (Long mu 801), alfalfa (Long mu 803), two kinds of alkali grass, corn silage and corn straw were used as raw materials for experiments. All the materials used in this experiment were collected from three different places (SBM, SFM, barley, corn, WB, CFF, alfalfa (Zhao dong), corn silage and corn straw from the Northeast of China, CSM, alfalfa (Long mu 801), alfalfa (Long mu 803) and one of alkali grass from the North of China, RSM from the Southwest of China, the other of alkali grass from Inner Mongolia of China). All feed samples and rumen residues were then ground through 2-mm screen.

\section{Animals and feeding}

Three dairy cows $(560 \pm 25 \mathrm{~kg})$ equipped with a rumen fistula (Bar Diamond, Parma, ID, USA) and T-shaped duodenal fistulas were selected for the in situ analysis of the rumen degradation rate and intestinal digestibility in this study. The procedures for ruminal and intestinal fistula surgery and the experimental protocol were approved by both Animal Science and Technology College of Northeast Agricultural University and Animal Care and Use Committee. The diet was formulated according to the NRC (2001), which consisted roughages and concentrates $(23.5 \%$ corn, 20\% distillers dried grains (DDG), 15\% RSM, 14\% SFM, $11 \%$ RB meal, $6 \%$ molasses, $5.5 \%$ pulp meal, $2 \%$ vitamins and minerals; on a dry matter [DM] basis) at a ratio of 60:40.

\section{Methods}

Residues after ruminal incubation were collected from the rumen nylon bag technique proposed by Heplund and Weisbjerg (2000). Three dairy cows $(560 \pm 25 \mathrm{~kg})$ equipped with a rumen fistula (Bar Diamond, USA) and T-shaped duodenal fistulas were chosen for the in situ analysis of the rumen degradation rate and intestinal digestibility in this study. Feed samples $(2.5 \mathrm{~g})$ were placed in nylon-coated bags $(10 \times 20 \mathrm{~cm})$ with a pore size of approximately $50 \mu \mathrm{m}$ as per NRC (2001) suggestion where the ratio of sample size to surface area of nylon bags should be $12.3 \mathrm{mg} / \mathrm{cm}^{2}$ (Maiga et al., 1996). Triplicate nylon bags were put into the rumen of each dairy cows to be incubated for 2, 4, 8, 16, 24, 48 , and $72 \mathrm{~h}$ ( 3 bags for each dairy cow at each time point) 
respectively except for the $16 \mathrm{~h}$ time point, the number of bags was twice that of the other time points, as the rumen residues left after that time point were needed to be collected to determine DRUP values. The other bags were used to determine rumen degradation rates. At each time point before incubation, the bags were fastened with a stainless-steel weight, and placed in the ventral sac of the rumen before rumen incubation. At the last time point, all the bags were removed at the same time. After removal of all bags from rumen, they were removed from the rumen, they were immersed in cold water immediately to wash until the rinse water was clear, and dried at $65^{\circ} \mathrm{C}$ for $48 \mathrm{~h}$. The purine derivatives of the microorganism were to obtained by rinsing the residue in a neutral detergent solution for roughages (Klopfenstein et al., 2001). Only the rumen undegradable residues collected after $16 \mathrm{~h}$ were transferred into nitrogen-free polyester bags $(3.5 \times 5.5 \mathrm{~cm}$, pore size $50 \pm 15$ um; R510 Ankom products; Ankom, NY, USA) to be pretreated for $1 \mathrm{~h}$ with pepsin before continuing to determine intestinal digestibility. Therefore, all the bags incubated for $16 \mathrm{~h}$ in the rumen were treated in a $0.1 \mathrm{~N} \mathrm{HCl}$ solution containing pepsin (1 g/L; Sigma P7000; Sigma, Oakville, ON, Canada) for $1 \mathrm{~h}$ at $39^{\circ} \mathrm{C}$, which could be served as the abomasal digestion. Among all the 27 bags incubated in the small intestine for $16 \mathrm{~h}, 9$ bags $(1 \mathrm{~g}$ taken out from each rumen bag and 3 rumen bags from each cow) were used to determine small intestine digestibility by the OTS procedure designed by Calsamiglia and Stern (1995), and 9 bags by the MTS method (Gargallo et al., 2006), and the remaining 9 bags by the MNB method (Hvelplund et al., 1992).

\section{Chemical analysis}

Dry matter, ether extract (EE) and $\mathrm{CP}$ contents were analyzed according to AOAC (2000) procedures. Following the produre of Van Soest et al. (1991) who adopted the Ankom system (Ankom 220 fiber analyzer; Ankom, USA) with heat-stable $\alpha$-amylase, the experiment analyzed the analysis of the neutral detergent fiber (NDF) and acid detergent fiber (ADF). The Cornel Net Carbohydrate and Protein System defined nitrogen fractions of the samples were determined by the method described by Licitra et al. (1996).

\section{Equations for calculations}

Determined DRUP values derived from the mobile nylon bag method, the OTS method and the MTS method were calculated by the following equation:

DRUP $(\%)=$ (rumen undegraded protein content residual protein content) $\times 100 /$ rumen undegraded protein content
Predicted DRUP values derived from the ADIN estimated method were calculated by the following equation:

DRUP $(\%)=$ (rumen undegraded protein content ADIN protein content) $\times 100 /$ rumen undegraded protein content

\section{Statistics analysis}

The general linear model procedure of SAS (1999) was used to analyze the differences of the intestinal digestibility of RUP in the different methods. Multiple comparisons of mean were performed using Duncan procedure of SAS, and statistical differences were declared at $\mathrm{p}<0.05$ using Tukey's test. The PROC CORR procedure of SAS (1999) was used to make the correlation analysis for DRUP values between the MNB method and other methods. PROC REG of SAS (1999) was used to perform stepwise multiple regression analysis to identify significant explanatory variables between general nutrients contents and the DRUP values.

\section{RESULTS}

\section{Determination of DRUP values of feed by three methods and correlation analysis}

The determined DRUP values of the concentrates using the MNB, MTS, and OTS methods are presented in Table 2. The determined DRUP values of the SBM, corn and barley using the MNB method were the highest (all above 90\%), followed by CGM, RSM, and SFM (all above $80 \%$ ). The determined DRUP values of CFF, CGM, WB, and RB using the MNB method were below $80 \%$, and RB had the lowest DRUP values $(69.27 \%)$. For the concentrates, no significant differences were observed between the obtained DRUP values of the CSM, RSM, SFM, and CGM using MTS method and those using MNB method ( $p>0.05)$. However, the determined DRUP values of the SBM, corn, RB, barley, WB and corn CFF using the MTS method were lower than those using the MNB method $(\mathrm{p}<0.05)$. The determined DRUP values of all the feed samples using the OTS method were lower than those using the MNB method $(\mathrm{p}<0.05)$.

For the roughages in Table 2, alfalfa (Zhaodong, Longmu 801, and Longmu 803) had higher determined DRUP values (above 60\%) using the MNB method than other roughages. Among all types of alfalfa, alfalfa (Longmu 803) had the highest $(73.57 \%$ ) determined DRUP values, then alfalfa (Longmu 801) (68.64\%), and alfalfa (Zhaodong) (66.72) had the lowest DRUP. Corn silage, grass (Inner Mongolia) and grass (North) followed, and their determined DRUP values using the MNB method were $54.05 \%, 51.52 \%$, and $50.47 \%$, respectively. Corn straw had the lowest value (43.84\%). Determined DRUP values using the MTS and OTS methods were significantly lower than 


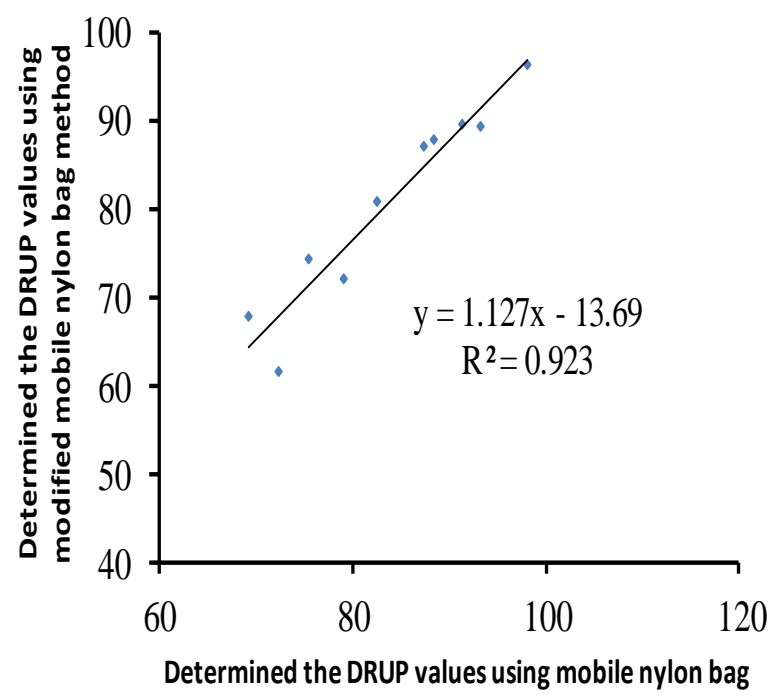

Figure 1. Predicted analysis between MNB observed values and MTS observed value in the concentrates. MNB, mobile nylon bag method; MTS, modified three-step in vitro method.

those values using the MNB method $(\mathrm{p}<0.05)$ for the roughages.

Correlation coefficients of the determined DRUP values in three types (protein supplements, energy feeds, and roughages) between the MNB method and other methods are presented in Table 6 , and a correlation matrix of determined DRUP values between the MNB method and other methods is list in Table 7. In terms of the concentrates, the determined DRUP values had a significant correlation between the MTS and MNB methods $(r=0.982, \mathrm{p}<0.01)$, and so did the values between the OTS and MNB methods $(r=0.972, \mathrm{p}<0.01)$. The DRUP values determined by the MTS and MNB methods could be predicted by the equation( $\left.\mathrm{y}=1.127 \mathrm{x}-13.69 ; R^{2}=0.923\right)$ (Figure 1 ), and those

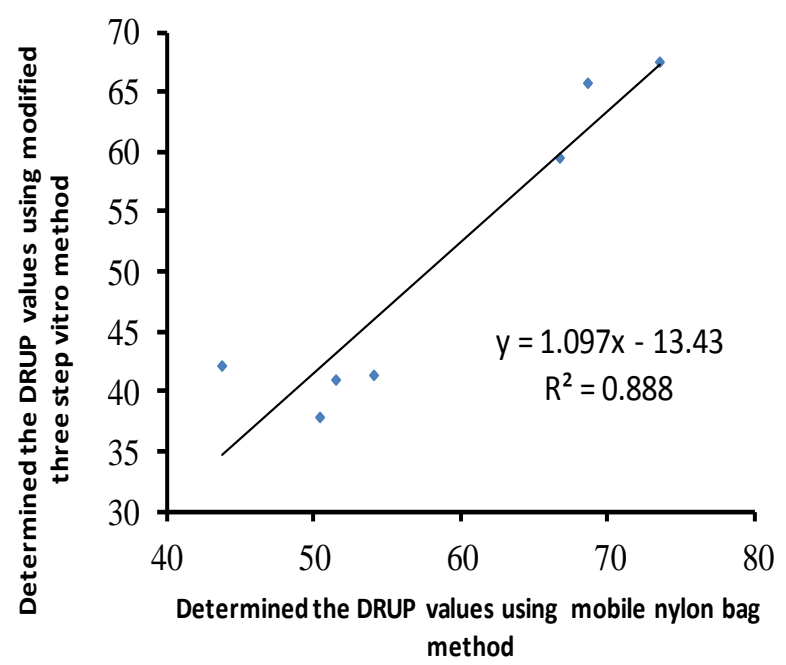

Figure 2. Predicted analysis between MNB observed values MTS observed value in the roughages. MNB, mobile nylon bag method; MTS, modified three-step in vitro method.

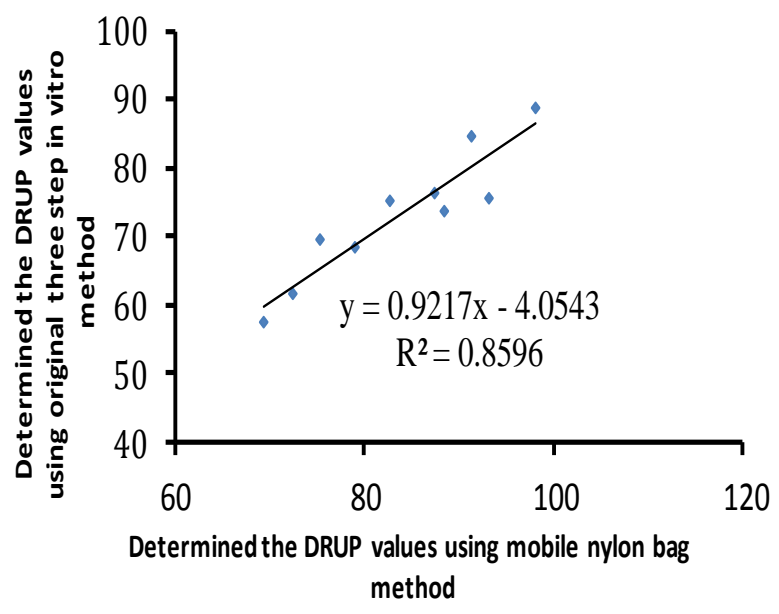

Figure 3. Predicted analysis between MNB observed values and OTS observed value in the concentrates. DRUP, digestibility of rumen undegradable protein; MNB, mobile nylon bag method; OTS, original three-step in vitro method.

by the OTS and MNB methods could be predicted by the equation ( $\mathrm{y}=0.921 \mathrm{x}-4.054, R^{2}=0.859$ ) (Figure 3). Referring to roughages, the determined DRUP values between the MTS and MNB methods had a significant correlation $(r=0.927, \mathrm{p}<0.01)$ and could be predicted by the equation ( $\left.\mathrm{y}=1.097 \mathrm{x}-13.43, R^{2}=0.888\right)$ (Figure 2). The determined DRUP values between the OTS and MNB methods also had a significant correlation $(r=0.928$, $\mathrm{p}<$ $0.01)$ and could be predicted by the equation ( $\mathrm{y}=1.026 \mathrm{x}-$ 12.74, $R^{2}=0.86$ ) (Figure 4). The coefficient of determination $\left(R^{2}\right)$ means the degree of fitting of the predicted equation, and the determination coefficient of the determined DRUP values between the MTS and MNB methods $\left(R^{2}=0.965\right)$ was higher than that between the OTS and MNB methods $\left(R^{2}=0.944\right)$ (Figures 5 and 6,

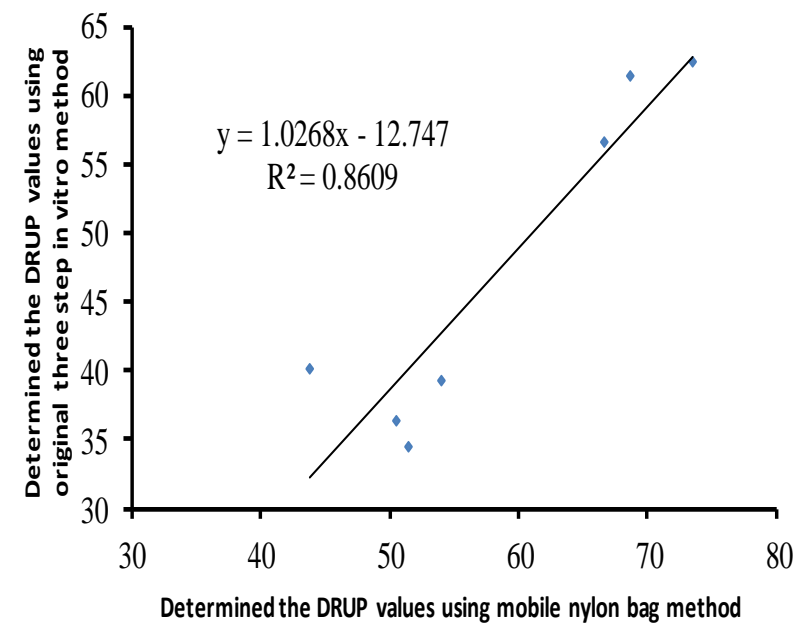

Figure 4. Predicted analysis between MNB observed values and OTS observed value in the roughages. DRUP, digestibility of rumen undegradable protein; MNB, mobile nylon bag method; OTS, original three-step in vitro method. 


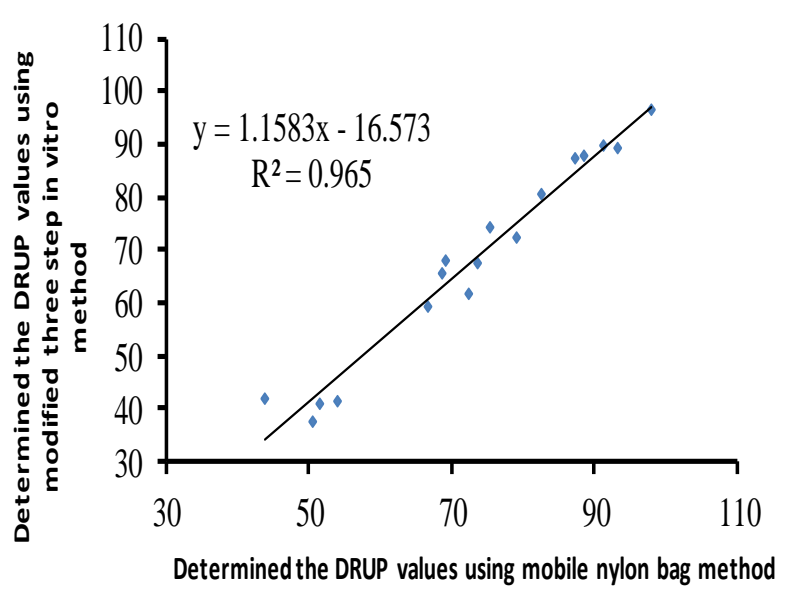

Figure 5. Predicted analysis between MNB observed values and MTS observed values in all the samples. DRUP, digestibility of rumen undegradable protein; MNB, mobile nylon bag method; MTS, modified three-step in vitro method.

respectively).

Correlation analysis between the estimated DRUP values using the ADIN method and the determined DRUP values using the MNB method

The estimated DRUP values using the ADIN method and the determined DRUP values using the MNB method are presented in Table 3. For the concentrates, the highest estimated DRUP values (all above $80 \%$ ) were observed in SBM, SFM, and barley using the ADIN method and the lowest value $(67.45 \%)$ was observed in CGM. Alfalfa (Long mu 803) (75.60\%), alfalfa (Long mu 801) (73.33\%), alfalfa (Zhaodong) $(69.38 \%)$ and corn silage $(69.14 \%)$ had

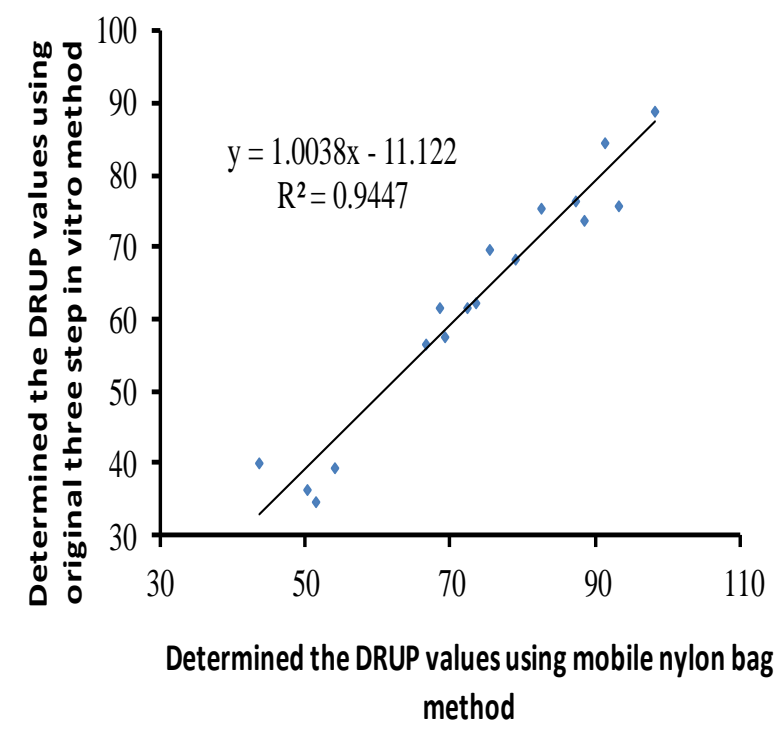

Figure 6. Predicted analysis between MNB observed values and OTS observed values in all the samples. DRUP, digestibility of rumen undegradable protein; MNB, mobile nylon bag method; OTS, original three-step in vitro method.

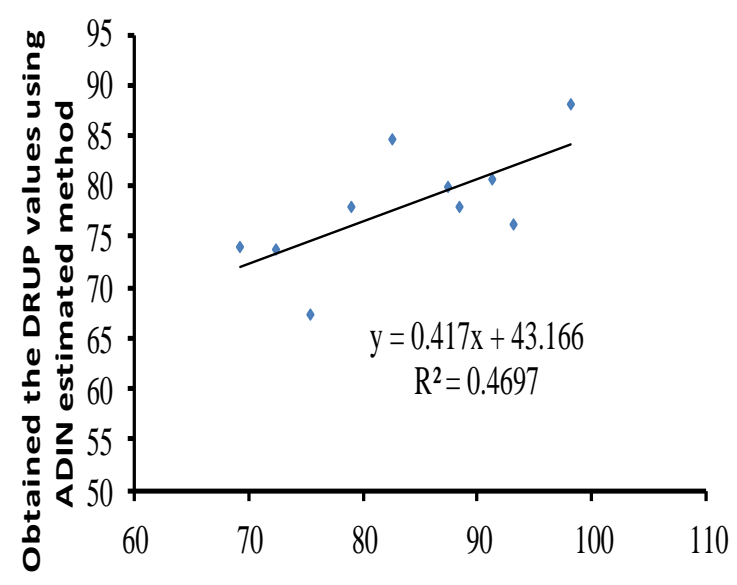

\section{Determined the DRUP values using mobile nylon bag method}

Figure 7. Predicted analysis between MNB determined values and ADIN estimated values in the concentrates. DRUP, digestibility of rumen undegradable protein; MNB, mobile nylon bag method; ADIN, acid detergent insoluble nitrogen method.

the highest determined DRUP values using the ADIN estimated method, followed by grass (North) (66.93\%) and grass (Inner Mongolia) (66.68\%), and it is lower in corn straw (56.69\%). The estimated DRUP values using the ADIN method and the determined DRUP values using the MNB method had no significant difference for the alfalfa (Zhaodong) ( $p>0.05)$. However, the estimated DRUP values using the ADIN method for other roughages were higher than the determined DRUP values using the MNB method $(p<0.05)$. In Table 6, compared with the significant correlation between the estimated DRUP values using the ADIN method and the determined DRUP values using the MNB method $(r=0.928, \mathrm{p}<0.01)$ for roughages, there was weak correlation for concentrates $(r=0.685, \mathrm{p}<0.05)$ between the estimated DRUP values using the ADIN method and the determined DRUP values using the MNB method. The coefficient of the determination $\left(R^{2}\right)$ of predicted equation between estimated DRUP values using the ADIN method and the determined DRUP values using the MNB method for roughages was higher than that for the concentrate (Figures 7 and 8, respectively).

\section{Regression relation between the DRUP values and routine nutrient content of the feed}

The routine nutrient content and determined DRUP values of all the samples using the MNB method are presented in Table 1. Their recursive regression equations are presented in Table 4. There was a significant correlation between DRUP values and CP, SP, NDF, EE (positive correlation between the DRUP values and the CP content; there was a negative correlation between the DRUP values and the SP, NDF, and EE content). When more variables 


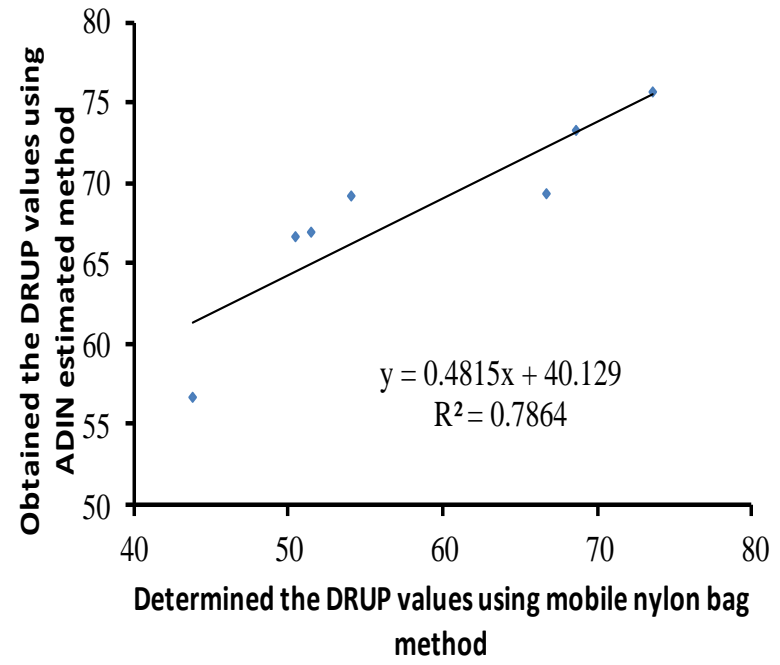

Figure 8. Predicted analysis between MNB observed values and ADIN estimated value in the roughages. DRUP, digestibility of rumen undegradable protein; MNB, mobile nylon bag method; ADIN, acid detergent insoluble nitrogen method.

were introduced into the equation, regression coefficients increased. When CP, NDF, EE were introduced into the equation, the regression equation was: DRUP = $100.5566+0.4169 \mathrm{CP}-0.4344 \mathrm{SP}-0.7102 \mathrm{NDF}-0.7950 \mathrm{EE}$ $\left(R^{2}=0.8668, \mathrm{p}<0.01 ; \mathrm{SP}\right.$, soluble protein $)$.

\section{DISCUSSION}

Comparison and analysis of the determined DRUP values using three different methods

In this study, the 10 kinds of concentrates (including 5 kinds of protein supplements and 5 kinds of energy feed) and 7 kinds of roughages are selected, and these feed have characteristics of almost all the feed in China, such as the class of protein characteristics, high (protein supplements), media (energy feeds) and low (roughages), which may influence the method used for analyzing DRUP values. Soybean meal was the most commonly used protein supplements for dairy cattle in North America, and it has the highest content of essential amino acids (Erasmus et al., 1994), it is also highly produced in China. Except SBM, all other protein supplements RSM, CSM, CGM, and SFM were selected based on other reports ( $\mathrm{Li}$ et al., 2011). Max et al. (2013) considered SBM, RSM, and CGM as raw materials. Therefore, SBM, CSF, RSM, SFM, and CGM were selected in our study. In China, corn, rice wheat and barley were widely grown, and the amount of byproduct of them was high. Van Straalen and FMH Dooper (1993) used grass silage, grass, and clover as raw materials, which was different from the present study, the reason was that different climatic conditions, soil environment and regions lead to different species in China, therefore alfalfa (Long mu 801), alfalfa (Long mu 803), alkali grass, corn silage, and corn straw were selected in this study.

On average, the determined DRUP value of SBM was $98.13 \%$, which was similar to the value (98.5\% to $99 \%)$ reported by Beckers et al. (1996) and Frydrch (1992). The determined DRUP value of CSM using the MNB method was similar to the results calculated by Woods et al. (2003). In this experiment, the average determined DRUP value of roughages (grass, alfalfa, corn silage, corn straw) DRUP value was $58 \pm 12 \%$, which was similar to the estimations ranging from $60 \%$ to $70 \%$ as reported by NRC (2001). The NRC (2001) emphasizes that the DRUP is $70 \%$ for corn silage, which is higher than the value (54.05\%) observed in this experiment. Although this value is lower, it is consistent with a previous study (Haugen et al., 2006), suggests that the DRUP values from NRC (2001) may be overestimated. Compared with several concentrates, only a small proportion of forage $\mathrm{CP}$ was degraded in the small intestine. This is because it is associated with cell wall proteins, which are difficult to be digested by enzyme other than rumen bacteria. On the other hand, most of the foraged CP was highly proteolysed in the rumen resulting from the leaf protein in the forages (Van Straalen and Tammiga, 1990).

The experimental results for alfalfa were slightly higher than the earlier reported results, which might be affected by the rumen cultivation time, varieties, harvesting time, and microorganism pollution of alfalfa (De Boer et al., 1987). The 16 hours of incubation in the rumen may reflect the process of rumen degradation for all types of the concentrates, but for the roughages, varieties may be greatly affected by the cultivation time greatly, which may result in different DRUP values. The longer the rumen degradation time is, the little the intestine digestibility of RUP becomes, but prolong incubation time in the rumen would lead to no change (Hveplund et al., 2000), and one possible reason for the observed discrepancy is the use of correcting for microbial biomass from residual particles that may influence estimation of $\mathrm{N}$ digestibility. By summarizing the rumen degradability and small intestine digestibility of 16 types of alfalfa and 14 types of grass, Von Keyserlongk et al. (1996) concluded that the DRUP values of roughages were affected by rumen cultivation time.

A series of findings has been published concerning the determined DRUP values, and their estimations are influenced greatly by the methods being used (such as MNB, OTS, MTS, and ADIN). Using the original and modified 3 step procedures, Keinschmit et al. (2007) evaluated the intestinal digestibility of different SBM products, and reported that the mean for SBM was $86.7 \%$ and the discrepancy between the original and modified 3step method was small. Intestinally digestible protein from DDG products varied from $91.4 \%$ to $93.5 \%$, and these values are in agreement with results obtained from either the mobile bag technique (Kononoff et al., 2006; Janicek et 
Table 1. Determined samples nutrients content of protein supplements (DM basis)

\begin{tabular}{|c|c|c|c|c|c|c|c|c|}
\hline Sample (\%) & $\mathrm{CP}$ & SP & NDICP & ADICP & NPN & NDF & ADF & $\mathrm{EE}$ \\
\hline $\begin{array}{l}\text { Soybean meal } \\
\text { (Northeast) }\end{array}$ & $49.73 \pm 0.75$ & $12.9 \pm 1.50$ & $0.67 \pm 0.09$ & $0.46 \pm 0.09$ & $5.95 \pm 0.19$ & $15.94 \pm 0.22$ & $6.97 \pm 0.4$ & $1.77 \pm 0.11$ \\
\hline $\begin{array}{l}\text { Cotton meal } \\
\text { (North) }\end{array}$ & $47.30 \pm 0.55$ & $6.80 \pm 0.61$ & $3.35 \pm 0.13$ & $2.56 \pm 0.39$ & $4.64 \pm 0.34$ & $39.98 \pm 0.24$ & $22.63 \pm 0.18$ & $1.83 \pm 0.09$ \\
\hline $\begin{array}{l}\text { Rapeseed meal } \\
\text { (Southwest ) }\end{array}$ & $39.33 \pm 0.52$ & $10.20 \pm 1.02$ & $6.33 \pm 0.12$ & $2.55 \pm 0.32$ & $6.64 \pm 0.31$ & $29.31 \pm 0.43$ & $19.33 \pm 0.25$ & $2.70 \pm 0.32$ \\
\hline $\begin{array}{l}\text { Sunflower meal } \\
\text { (Northeast) }\end{array}$ & $30.87 \pm 0.31$ & $10.69 \pm 0.33$ & $2.04 \pm 0.17$ & $1.10 \pm 0.17$ & $9.46 \pm 0.41$ & $49.94 \pm 0.35$ & $29.34 \pm 0.22$ & $2.76 \pm 0.11$ \\
\hline $\begin{array}{l}\text { Corn germ meal } \\
\text { (Northeast) }\end{array}$ & $26.33 \pm 0.34$ & $13.77 \pm 0.38$ & $3.14 \pm 0.14$ & $2.35 \pm 0.10$ & $10.13 \pm 0.19$ & $37.90 \pm 0.69$ & $9.76 \pm 0.14$ & $1.68 \pm 0.04$ \\
\hline $\begin{array}{l}\text { Corn } \\
\text { (Northeast) }\end{array}$ & $8.80 \pm 0.17$ & $1.51 \pm 0.27$ & $1.17 \pm 0.09$ & $0.89 \pm 0.23$ & $1.07 \pm 0.11$ & $18.45 \pm 0.13$ & $2.07 \pm 0.28$ & $4.60 \pm 0.28$ \\
\hline $\begin{array}{l}\text { Rice Bran } \\
\text { (Northeast) }\end{array}$ & $13.11 \pm 0.20$ & $3.69 \pm 0.27$ & $3.76 \pm 0.20$ & $0.71 \pm 0.07$ & $3.33 \pm 0.21$ & $32.90 \pm 0.65$ & $14.50 \pm 0.26$ & $15.27 \pm 0.37$ \\
\hline $\begin{array}{l}\text { Barley } \\
\text { (Northeast) }\end{array}$ & $10.99 \pm 0.25$ & $2.86 \pm 0.27$ & $1.75 \pm 0.13$ & $1.20 \pm 0.20$ & $1.87 \pm 0.19$ & $8.38 \pm 0.36$ & $6.24 \pm 0.21$ & $3.83 \pm 0.61$ \\
\hline $\begin{array}{l}\text { Wheat bran } \\
\text { (Northeast) }\end{array}$ & $19.22 \pm 0.16$ & $2.83 \pm 0.32$ & $2.74 \pm 0.19$ & $0.80 \pm 0.19$ & $2.13 \pm 0.11$ & $41.24 \pm 0.30$ & $12.86 \pm 0.18$ & $2.89 \pm 0.16$ \\
\hline $\begin{array}{l}\text { Corn fiber feed } \\
\text { (Northeast) }\end{array}$ & $9.28 \pm 0.08$ & $3.05 \pm 0.17$ & $1.76 \pm 0.12$ & $0.68 \pm 0.17$ & $2.77 \pm 0.12$ & $50.96 \pm 1.09$ & $12.08 \pm 0.29$ & $0.94 \pm 0.17$ \\
\hline $\begin{array}{l}\text { Alfalfa } \\
\text { (Zhaodong) }\end{array}$ & $20.20 \pm 0.60$ & $12.96 \pm 2.45$ & $2.35 \pm 0.12$ & $1.05 \pm 0.06$ & $11.66 \pm 0.22$ & $45.02 \pm 1.10$ & $33.23 \pm 0.38$ & $2.63 \pm 0.18$ \\
\hline $\begin{array}{l}\text { Alfalfa } \\
\text { (Long mu 801) }\end{array}$ & $20.16 \pm 1.25$ & $12.12 \pm 0.41$ & $2.35 \pm 0.07$ & $0.98 \pm 0.07$ & $11.69 \pm 0.24$ & $45.44 \pm 0.84$ & $33.37 \pm 0.41$ & $3.18 \pm 0.18$ \\
\hline $\begin{array}{l}\text { Alfalfa } \\
\text { (Long mu 803) }\end{array}$ & $21.08 \pm 0.27$ & $12.29 \pm 0.28$ & $2.65 \pm 0.10$ & $0.96 \pm 0.09$ & $11.48 \pm 0.22$ & $47.02 \pm 0.58$ & $34.55 \pm 0.38$ & $2.84 \pm 0.14$ \\
\hline $\begin{array}{l}\text { Grass } \\
\text { (North) }\end{array}$ & $8.52 \pm 0.26$ & $3.43 \pm 0.31$ & $2.10 \pm 0.14$ & $1.35 \pm 0.03$ & $2.98 \pm 0.17$ & $68.32 \pm 0.77$ & $36.54 \pm 1.17$ & $3.15 \pm 0.23$ \\
\hline $\begin{array}{l}\text { Grass } \\
\text { (Inner Mongolia) }\end{array}$ & $8.85 \pm 2.56$ & $3.37 \pm 0.16$ & $2.11 \pm 0.12$ & $1.30 \pm 0.06$ & $1.83 \pm 0.08$ & $66.79 \pm 0.73$ & $34.32 \pm 0.35$ & $3.12 \pm 0.16$ \\
\hline $\begin{array}{l}\text { Corn silage } \\
\text { (Northeast) }\end{array}$ & $10.33 \pm 0.26$ & $7.00 \pm 0.14$ & $1.99 \pm 0.15$ & $0.99 \pm 0.05$ & $6.74 \pm 0.13$ & $51.20 \pm 0.41$ & $27.93 \pm 0.30$ & $3.00 \pm 0.15$ \\
\hline $\begin{array}{l}\text { Corn straw } \\
\text { (Northeast) }\end{array}$ & $4.270 \pm 0.09$ & $1.25 \pm 0.12$ & $1.74 \pm 0.09$ & $1.33 \pm 0.09$ & $1.05 \pm 0.10$ & $69.65 \pm 0.78$ & $37.40 \pm 0.84$ & $1.78 \pm 0.09$ \\
\hline
\end{tabular}

DM, dry matter; CP, crude protein; SP, soluble protein; NDICP, neutral detergent insoluble protein; ADICP, acid detergent insoluble protein; NPN, nonprotein nitrogen; NDF, neutral detergent fiber; ADF, acid detergent fiber; EE, ether extract.

al., 2008) or the modified 3-step procedure (Boucher et al., 2009b). When determining foraged samples, these methods demonstrated to be highly correlated, but in vitro method was also proven to be less variable and less laborious (Klopfenstein et al., 2001). However, Wood et al. (2003) reported higher DRUP valuesin in situ methods compared with in vitro methods in SBM. Hvelplund (1985) also reported a similar result in which the determined DRUP values using the MNB method were higher than those using the in vitro method. In this experiment, the determined DRUP values of most feeds using the OTS method and MTS method were lower than those using the MNB method, probably due to the samples incubated in the mobile nylon bags experienced the digestion of the large intestine (Calsamiglia and Stern, 1995). Mobile nylon bags were from the feces, and the disappearance of DM, CP, and amino acids were calculated by adding both of the disappearance in the small intestine and large intestine. Although the latter was not measured in our experiment, other studies reported that large intestine fermentation has only a limited effect on total intestinal disappearance both in nylon bags (Voigt et al., 1985; Van straalen, 1997) and in vivo experiments (Van straalen and Tammigna, 1990). In addition, the higher digestion values for the in situ method could be explained by the fact that the in vitro activity of some enzyme was lower than that in vivo, so portions of RUP would not be decomposed by an in vitro enzyme, and an artificially designed technique to study enzymatic digestion is unlikely to exactly represent the environment or the function of the intestine exactly (Van straalen et al., 1993; Stern et al., 1997). Furthermore, particles lost from the mobile bags during the intestinal transit or materials lost 
Table 2. The feed DRUP values measured by mobile nylon bag method, original three-step in vitro method and modified threestep in vitro method

\begin{tabular}{lllll}
\hline Feed kinds & MNB & MTS & OTS & SEM \\
\hline Concentrates & & & & \\
Soybean meal (Northeast) & $98.13^{\mathrm{a}}$ & $96.33^{\mathrm{b}}$ & $88.80^{\mathrm{c}}$ & 1.44 \\
Cotton meal (North ) & $87.37^{\mathrm{a}}$ & $87.13^{\mathrm{a}}$ & $76.17^{\mathrm{b}}$ & 1.86 \\
Rapeseed meal & $88.47^{\mathrm{a}}$ & $87.70^{\mathrm{a}}$ & $73.77^{\mathrm{b}}$ & 2.40 \\
$\quad$ (Southwest) & & & & \\
Sunflower meal & $82.60^{\mathrm{a}}$ & $80.77^{\mathrm{a}}$ & $75.37^{\mathrm{b}}$ & 1.13 \\
$\quad$ (Northeast) & & & & \\
Corn germ meal & $75.40^{\mathrm{a}}$ & $74.33^{\mathrm{a}}$ & $69.57^{\mathrm{b}}$ & 0.95 \\
$\quad$ (Northeast) & & & & \\
Corn (Northeast) & $93.23^{\mathrm{a}}$ & $89.27^{\mathrm{b}}$ & $75.57^{\mathrm{c}}$ & 2.68 \\
Rice bran (Northeast) & $69.27^{\mathrm{a}}$ & $67.87^{\mathrm{b}}$ & $57.57^{\mathrm{c}}$ & 1.85 \\
Barley (Northeast) & $91.27^{\mathrm{a}}$ & $89.57^{\mathrm{b}}$ & $84.53^{\mathrm{c}}$ & 1.04 \\
Wheat bran (Northeast) & $72.37^{\mathrm{a}}$ & $61.63^{\mathrm{b}}$ & $61.40^{\mathrm{b}}$ & 0.95 \\
Corn fiber feed & $79.03^{\mathrm{a}}$ & $72.10^{\mathrm{b}}$ & $68.33^{\mathrm{c}}$ & 1.57 \\
$\quad$ Northeast) & & & & \\
Roughages & & & & \\
Alfalfa (Zhaodong) & $66.72^{\mathrm{a}}$ & $59.48^{\mathrm{b}}$ & $56.58^{\mathrm{c}}$ & 1.55 \\
Alfalfa (Long mu 801) & $68.64^{\mathrm{a}}$ & $65.78^{\mathrm{b}}$ & $61.41^{\mathrm{c}}$ & 1.08 \\
Alfalfa (Long mu 803) & $73.57^{\mathrm{a}}$ & $67.43^{\mathrm{b}}$ & $62.35^{\mathrm{c}}$ & 1.65 \\
Grass (North) & $50.47^{\mathrm{a}}$ & $37.74^{\mathrm{b}}$ & $36.38^{\mathrm{b}}$ & 2.46 \\
Grass (Inner Mongolia) & $51.52^{\mathrm{a}}$ & $40.88^{\mathrm{b}}$ & $34.44^{\mathrm{c}}$ & 2.26 \\
Corn silage (Northeast) & $54.05^{\mathrm{a}}$ & $41.34^{\mathrm{b}}$ & $39.30^{\mathrm{b}}$ & 2.33 \\
Corn straw (Northeast) & $43.84^{\mathrm{a}}$ & $42.06^{\mathrm{b}}$ & $40.06^{\mathrm{c}}$ & 0.58 \\
\hline
\end{tabular}

MNB, mobile nylon bag method; MTS, modified three-step in vitro method; OTS, original three-step in vitro method; SEM, standard error mean.

Values with different small letter superscripts mean significant difference in the same row $(\mathrm{p}<0.05)$.

during machine washing of the bags could be additional factors to explain the higher values observed in the in situ method. Other major factors that influence the estimations of DRUP could include the bag specifications (Varvikho and Vanhatalo, 1991) and the condition of the bags retrieved (ileum vs feces; Hveplund and Weisbjerg, 2000).

For forages, the neutral detergent solution is assumed to remove the microbes attached to the particles of samples without affecting RUP. The values of non-fiber forage source energy feeds, such as corn, RB, and barley, in this experiment, they were higher than previous values, because a portion of the proteins may have possibly remained in the residues, which resulted in low estimations of undegradable
Table 3. The DRUP measured by mobile nylon method and ADIN estimation method (DM basis)

\begin{tabular}{llll}
\hline Sample & MNB & ADIN & SEM \\
\hline Concentrates & & & \\
Soybean meal (Northeast) & $98.13^{\mathrm{a}}$ & $88.11^{\mathrm{b}}$ & 0.38 \\
Cotton meal (North) & $87.37^{\mathrm{a}}$ & $79.86^{\mathrm{b}}$ & 1.59 \\
Rapeseed meal (Southwest) & $88.47^{\mathrm{a}}$ & $78.07^{\mathrm{b}}$ & 3.08 \\
Sunflower meal (Northeast) & $82.60^{\mathrm{a}}$ & $84.63^{\mathrm{a}}$ & 1.44 \\
Corn germ meal (Northeast) & $75.40^{\mathrm{a}}$ & $67.45^{\mathrm{b}}$ & 2.20 \\
Corn (Northeast) & $93.23^{\mathrm{a}}$ & $76.34^{\mathrm{b}}$ & 1.45 \\
Rice bran(Northeast) & $69.27^{\mathrm{b}}$ & $74.08^{\mathrm{a}}$ & 0.22 \\
Barley (Northeast) & $91.27^{\mathrm{a}}$ & $80.57^{\mathrm{b}}$ & 3.09 \\
Wheat bran (Northeast) & $72.37^{\mathrm{a}}$ & $73.71^{\mathrm{a}}$ & 8.28 \\
Corn fiber feed (Northeast) & $79.03^{\mathrm{a}}$ & $77.94^{\mathrm{a}}$ & 3.92 \\
Roughages & & & \\
Alfalfa (Zhaodong) & $66.72^{\mathrm{a}}$ & $69.38^{\mathrm{a}}$ & 1.58 \\
Alfalfa (Long mu 801) & $68.64^{\mathrm{b}}$ & $73.33^{\mathrm{a}}$ & 0.72 \\
Alfalfa (Long mu 803) & $73.57^{\mathrm{b}}$ & $75.60^{\mathrm{a}}$ & 0.62 \\
Grass (North) & $50.47^{\mathrm{b}}$ & $66.68^{\mathrm{a}}$ & 0.55 \\
Grass (Inner Mongolia) & $51.52^{\mathrm{b}}$ & $66.93^{\mathrm{a}}$ & 1.46 \\
Corn silage (Northeast) & $54.05^{\mathrm{b}}$ & $69.14^{\mathrm{a}}$ & 0.60 \\
Corn straw (Northeast) & $43.84^{\mathrm{b}}$ & $56.69^{\mathrm{a}}$ & 0.79 \\
\hline
\end{tabular}

DRUP, digestibility of rumen undegradable protein; ADIN, acid detergent insoluble nitrogen method; DM, dry matter; MNB, mobile nylon bag method; SEM, standard error mean.

Values with different small letter superscripts mean significant difference in the same row $(\mathrm{p}<0.05)$.

rumen protein and high small intestine digestibility (Klopfenstein et al., 2001). In this experiment, microbial contamination in the samples of corn and protein supplements (SBM, CSM, RSM, SFM, CGM, corn) were not corrected because it is generally assumed that there is little microbial attachment to concentrate feeds. A similar result was reported by Frydrynch (1992).

In the concentrates, there were no significant differences between the determined DRUP values of the CSM, RSM, SFM, and CGM using the MTS method and those using the MNB method, which showed that the MNB method can be replaced by the MTS method to determine the DRUP values for these four feeds. The coefficient of determination $\left(R^{2}\right)$ of the obtained DRUP values between the MTS and MNB methods for the concentrates was higher $\left(R^{2}=0.923\right)$ than that for the roughage $\left(R^{2}=0.888\right)$, which showed that the determined DRUP values of the concentrates using the

Table 4. The regression equation of predicted digestibility of RUP

\begin{tabular}{llccc}
\hline \multicolumn{2}{l}{ Recursive regression equation } & $R^{2}$ & SEM & $\mathrm{p}$ value \\
\hline 1 & $\mathrm{Y}=-0.929 X_{2}+66.694$ & 0.071 & 16.14 & 0.3024 \\
2 & $\mathrm{Y}=60.591+0.889 X_{I}-0.777 X_{2}$ & 0.4197 & 13.20 & 0.0222 \\
3 & $\mathrm{Y}=58.752+0.899 X_{I}-0.731 X_{2}+0.383 X_{4}$ & 0.425 & 13.64 & 0.0589 \\
4 & $\mathrm{Y}=100.5566+0.4169 X_{I}-0.4344 X_{2}-0.7102 X_{3}-0.7950 X_{4}$ & 0.8668 & 6.83 & $<0.0001$ \\
\hline
\end{tabular}

RUP, rumen undegraded protein; SEM, standard error mean; CP, crude protein; DM, dry matter; SP, soluble protein; NDF, neutral detergent fiber; EE, ether extract. 
Table 5. The standard error of all of the parameter estimates of regression equation

\begin{tabular}{cccc}
\hline & Parameter estimate & SEM & $\mathrm{p}$ \\
\hline Equation 1 & & & \\
Intercept & 66.694 & 7.3129 & $<0.0001$ \\
$\mathrm{X}_{2}$ & 0.929 & 0.8698 & 0.3 \\
Equation 2 & & & \\
Intercept & 60.5910 & 6.3403 & $<0.0001$ \\
$\mathrm{X}_{1}$ & 0.8890 & 0.3064 & 0.0116 \\
$\mathrm{X}_{2}$ & -0.7772 & 0.9229 & 0.4139 \\
Equation 3 & & & \\
Intercept & 58.7519 & 8.4489 & $<0.0001$ \\
$\mathrm{X}_{1}$ & 0.8989 & 0.3178 & 0.0142 \\
$\mathrm{X}_{2}$ & -0.7306 & 0.9630 & 0.4616 \\
$\mathrm{X}_{4}$ & 0.3832 & 1.1120 & 0.7359 \\
Equation 4 & & & \\
Intercept & 100.5566 & 7.8609 & $<0.0001$ \\
$\mathrm{X}_{1}$ & 0.4169 & 0.1765 & 0.036 \\
$\mathrm{X}_{2}$ & -0.4344 & 0.4846 & 0.3877 \\
$\mathrm{X}_{3}$ & -0.7102 & 0.1125 & $<0.0001$ \\
$\mathrm{X}_{4}$ & -0.7950 & 0.5874 & 0.2008 \\
\hline
\end{tabular}

SEM, standard error mean; CP, crude protein; DM, dry matter; SP, soluble protein; NDF, neutral detergent fiber; EE, ether extract.

$\mathrm{X}_{1}, \mathrm{CP}(\% \mathrm{DM}) ; \mathrm{X}_{2}, \mathrm{SP}(\% \mathrm{DM}) ; \mathrm{X}_{3}, \mathrm{NDF}(\% \mathrm{DM}) ; \mathrm{X}_{4}, \mathrm{EE}(\% \mathrm{DM})$.

MTS method were closer to those using the MNB method compared with the roughages, which was consistent with Van Straalen et al. (1993). The roughage $\left(R^{2}=0.888\right)$ had slightly higher coefficient of determination $\left(R^{2}\right)$ of the determined DRUP values between MNB and OTS methods than that $\left(R^{2}=0.860\right)$ between the MNB and MTS methods, which showed that, for the roughages, the accuracy of the determined DRUP values using the OTS method was similar to that using the MTS method. However, the determined DRUP values for the concentrates $\left(R^{2}=0.923\right)$ had a higher coefficient of determination $\left(R^{2}\right)$ between the MNB and MTS methods than those between the MNB and OTS methods $\left(R^{2}=0.859\right)$, which also showed that the determined DRUP values using the MTS method had higher accuracy than those using the OTS method. The coefficient

Table 6. Correlative coefficients of the feed DRUP values measured by mobile nylon bag method and other methods

\begin{tabular}{lccc}
\hline $\begin{array}{c}\text { Correlative } \\
\text { coefficient }\end{array}$ & $\begin{array}{c}\text { MNB } \\
\text { and MTS }\end{array}$ & $\begin{array}{c}\text { MNB } \\
\text { and OTS }\end{array}$ & $\begin{array}{c}\text { MNB } \\
\text { and ADIN }\end{array}$ \\
\hline $\mathrm{r}_{1}$ & $0.982^{* *}$ & $0.972^{* *}$ & $0.877^{* *}$ \\
$\mathrm{r}_{2}$ & $0.961^{* *}$ & $0.927^{* *}$ & $0.685^{*}$ \\
$\mathrm{r}_{3}$ & $0.942^{* *}$ & $0.928^{* *}$ & $0.928^{* *}$ \\
\hline
\end{tabular}

DRUP, digestibility of rumen undegradable protein; MNB, mobile nylon bag method; MTS, modified three-step in vitro method; OTS, original three-step in vitro method; ADIN, acid detergent insoluble nitrogen method.

$r_{1}$, correlative coefficients of protein supplements; $r_{2}$, correlative coefficients of energy feed; $r_{3}$ correlative coefficients of roughage.

** Significant difference $(\mathrm{p}<0.01)$; * significant difference $(\mathrm{p}<0.05)$.
Table 7. The a correlation matrix of correlative coefficients of determined DRUP

\begin{tabular}{lcccc}
\hline $\begin{array}{c}\text { Correlative } \\
\text { coefficient }\end{array}$ & MNB & MTS & OTS & ADIN \\
\hline MNB & 1 & $0.982 * *$ & $0.972 * *$ & $0.877 * *$ \\
MTS & $0.982 * *$ & 1 & $0.982 * *$ & $0.831 * *$ \\
OTS & $0.972 * *$ & $0.982 * *$ & 1 & $0.839 * *$ \\
ADIN & $0.877 * *$ & $0.831 * *$ & $0.839 * *$ & 1 \\
\hline
\end{tabular}

DRUP, digestibility of rumen undegradable protein; MNB, mobile nylon bag method; MTS, modified three-step in vitro method; OTS, original three-step in vitro method; ADIN, acid detergent insoluble nitrogen method

** Significant difference $(\mathrm{p}<0.01)$; * significant difference $(\mathrm{p}<0.05)$.

of determination $\left(R^{2}\right)$ of the determined DRUP values between the MTS and MNB methods (0.964) was higher than that (0.942) between the OTS method and MNB method in all the samples, and both of these two coefficients of determination were higher than 0.90 , which also showed that both the OTS and MTS methods could replace the MNB method to determine the DRUP values. For the above predicted equation of the determined DRUP values using the MNB method and OTS method, the MTS method was based on the basis of correlation between them, and they had a strong correlation for concentrates, roughages of all the samples. These results were consistent with Van Straalen and Tamminga (1990) who concluded that the determined DRUP values a strong correlation between the in vitro method and MNB method $\left(R^{2}=0.90\right)$. The determined DRUP values have a good correlation between the MNB method and OTS method $\left(R^{2}=0.810\right)$, which are obtained by determining the DRUP values of four protein supplements from different sources (Antoniewicz et al., 1992). Woods et al. (2003) also described a strong correlation $\left(R^{2}=0.910\right)$ of the DRUP values between the MNB and OTS methods in 12 types of feeds, including SBM, SFM, RSM, CSM, palm meal, and barley. Similarly, other researchers also concluded that the determined DRUP values between the OTS method and the MNB method have a strong correlation (Hveplund et al., 1992; Qun et al., 2007). Gargallo et al. (2006) found that the MTS and OTS methods have a great correlation $\left(R^{2}=0.84\right)$. In this experiment, the coefficient of determination of the DRUP values in all samples between the MNB method and MTS method was higher than that between the MNB and OTS methods, which showed that the MTS method was better than the OTS method when it was used as the replacement for the MNB method, and also indicated that the MTS method for determining the DRUP values may imitate the small intestine environment better than the OTS method. There are many advantages of the MTS method: i) Pepsin used in the MTS method (P-7012) is much cheaper than that used in the OTS method (P-7000); ii) In the OTS method, trichloroacetic can be used to suspend the protein 
reaction, but it exhibits high corrosion and oxidation, which could cause environmental pollution; therefore, the reagent was replaced in MTS method; and iii) Small intestine digestibility of the rumen undegradable amino acid can be determined by the MTS method, but not the OTS method.

\section{Comparative analysis of the DRUP values between MNB and ADIN estimated methods}

Although the use of neutral detergent insoluble nitrogen to measure DRUP and the total tract digestibility of forage protein has been violated (Haugen et al., 2000), the use of ADIN to measure DRUP continued. There were no differences in the obtained DRUP values using the MNB method and ADIN estimated method in the SFM, corn germ feed and WB, which showed that the ADIN method can exactly predict the DRUP values of these three feedstuffs exactly. Compared with the positive correlation $\left(R^{2}=0.786\right.$, $\mathrm{p}<0.05)$ for the roughages, there was a weak correlation for the determined DRUP values of the concentrates between the MNB and ADIN methods, which showed that the determined DRUP values of some feeds (mainly roughage) can be predicted by the ADIN method, but for most feeds, it was not applicable. Many researchers show that the Maillard reaction could be produced in the course of processing the feeds. While ADIN could be increased, parts of the produced feed could be digested (Frydrynch, 1992). Therefore, the extent of the ADIN digestion is uncertain, which would hinder us from knowing the degree of degradation of ADIN produced by the Maillard reaction, and the determined DRUP values using the ADIN method are not always useful (NRC, 2001).

\section{Regression relation analysis between routine nutrient contents and the DRUP values}

The mobile nylon bag method has many disadvantages such as high price, long time period, and the use of a duodenal T-fistula, therefore, accurate methods for predicting DRUP values need to be explored. However, the mobile nylon bag method can not be replaced by the ADIN estimated method to determine the DRUP values in all the samples. In this experiment, routine nutrient contents had a significant correlation with DRUP values, and when more routine nutrient indexes were introduced, larger $R^{2}$ values appeared in the regression equation. When CP, SP, and NDF were introduced, and the $R^{2}$ value would be 0.425 ; when EE was also introduced, the $R^{2}$ value would be 0.869 , which meant that the predicted DRUP values were more accurate. Woods et al. (2003) found that the correlative coefficient was high between routine nutrient contents and the DRUP values obtained from the in vitro method $\left(R^{2}=0.78\right)$. When cows were not equipped with rumen fistulas or the experiment did not meet the demands of the in vitro method, the predicted method using routine nutrients may take the place of the MNB method.

\section{CONCLUSION}

i) The mobile nylon bag method can be replaced by the OTS and MTS methods to determine the DRUP values of feeds, and the determined DRUP values using the MTS method were closer to those obtained using MNB, compared with the OTS method. When compared with the roughage, the determined DRUP values of the concentrates using the MTS method were closer to those using the MNB method.

ii) The use of the ADIN method to predict the DRUP values of the feeds is limited, but routine nutrient contents are available.

iii) Estimates of the DRUP values may be influenced by the rumen incubation time, and further efforts should be aimed at methods to determine the rate of passage rapidly and accurately in cows.

\section{ACKNOWLEDGMENTS}

The authors thank the FARA project of Agriculture Ministry in China (CARS-37); The Youth Fund of Qiqihar University (2012k-Z06) and (2014k-M26) for financial support; Natural Science Foundation of Heilongjiang Province (C2015049); National Spark Program (2013 GA670002).

\section{REFERENCES}

Antoniewicz, A. M., A. M. van Vurren, C. J. van der Koelen, and I. Kosmala. 1992. Intestinal digestibility of rumen undegraded protein of formaldehyde-treated feedstuffs measured by mobile bag and in vitro technique. Anim. Feed Sci. Technol. 39:111124.

AOAC. 2000. Official Methods of Analysis. 17th ed. Association of Official Analytical Chemists, Arlington, VA, USA..

Beckers, Y., A. Thewis, and B. Maudoux. 1996. Intestinal digestibility of rumen undegraded $\mathrm{N}$ of concentrates measured by the mobile nylon bag technique. Anim. Feed Sci. Technol. 61: 305-323.

Boucher, S. E., C. Pedersen, H. H. Stein, and C. G. Schwab. 2009b. Evaluation of the furosine and homoarginine methods for determining reactive lysine in rumen-undegraded protein. $\mathrm{J}$. Dairy Sci. 92:3951-3958.

Calsamiglia, M. D. and S. Stern. 1995. A three-step in vitro procedure for estimating intestinal digestion of protein in ruminants. J. Anim. Sci. 73:1459-1462.

De Boer, G., J. J. Murphy, and J. J. Kennedy. 1987. Mobile nylon bag for estimating intestinal availability of rumen undegradable protein. J. Dairy Sci. 70:977-982.

Erasmus, L. J., P. M. Botha, and C. W. Cruywagen. 1994. Amino acid profile and intestinal digestibility in dairy cows of rumenundegradable protein from various feedstuffs. J. Dairy Sci. 77:541-551. 
Frydrynch, Z. 1992. Intestinal digestibility of rumen undegraded protein of various feeds as estimated by the mobile bag technique. Anim. Feed Sci. Technol. 37:161-172.

Gargallo, S., S. Calsamiglia, and A. Ferret. 2006. Technical note: A modified three-step in vitro procedure to determine intestinal digestion of proteins. J. Anim. Sci. 84:2163-2167.

Haugen, H. L., M. J. Lamothe, T. J. Klopfenstein, D. C. Adams, and M. D. Ullerich. 2005. Estimation of undegradable intake protein in forages using neutral detergent insoluble nitrogen at a single in situ incubation time point. J. Anim. Sci. 84:651-659.

Harstad, O. M. and E. Prestlkken. 2000. Effective rumen degradability and intestinal indigestibility of individual amino acids in solvent-extracted soybean meal (SBM) and xylosetreated SBM (SoyPass) determined in situ. Anim. Feed Sci. Technol. 83:31- 47.

Hvelplund, T. 1985. Digestibility of rumen microbial protein and undegraded dietary protein estimated in the small intestine of sheep and by in sxco procedure. Acta Agric. Stand. (Suppl. 25):132-144

Hvelplund, T., M. R. Weisbjerg, and L. S. Andersen. 1992. Estimation of the true digestibility of rumen undegraded dietary protein in the small intestine of ruminants by the mobile bag technique. Acta Agric. Scand. A. Anim. Sci. 42:3437.

Hvelplund, T. and M. R. Weisbjerg. 2000. In situ techniques for the estimation of protein digestibility and postrumen availability. In: Forage Evaluation in Ruminant Nutrition (Eds. D. I. Given, E. Owen, R. F. E. Ax ford, and H. M. Omed). CABI Pub 1. New York, NY, USA. pp. 233-258.

Janicek, B. N., P. J. Kononoff, A. M. Gehman, and P. H. Doane. 2008. The effect of feeding dried distillers grains plus solubles on milk production and excretion of urinary purine derivatives. J. Dairy Sci. 91:3544-3553.

Kusumanti, E., M. R Weisbjerg, and T. Hvelplund. 1996. A comparison between protein disappearance from the mobile bag and acid detergent solubility of nitrogenas estimates of protein digestibility in ruminants. J. Anim. Feed Sci. 5:337345.

Klopfenstein, T. J., R. A. Mass, K. W. Creighton, and H. H. Patterson. 2001. Estimating forage protein degradation in the rumen. J. Anim. Sci. 79 (Suppl. 1):208-217.

Kleinschmit, D. H., J. L. Anderson, D. J. Schingoethe, K. F. Kalscheur, and A. R. Hippen. 2007. Ruminal and intestinal digestibility of distillers grains plus solubles varies by source. J. Dairy Sci. 90:2909-2918.

Kononoff, P. J., S. K. Ivan, and T. J. Klopfenstein. 2007. Estimation of the proportion of feed protein digested in the small intestine of cattle consuming wet corn gluten feed. J. Dairy Sci. 90:2377-85.

Licitra, G., T. M. Hernandez, and P. J. Van Soest. 1996. Standardization of procedures for nitrogen fractionation of ruminant feeds. Anim. Feed Sci. Technol. 57:347-358.

Li, C., J. Q. Li, W. Z. Yang, and K. A. Beauchemin 2012. Ruminal and intestinal amino acid digestion of distiller's grain vary with grain source and milling process. Anim. Feed Sci. Technol. 175:121-130.

National Research Council (NRC). 1996. Nutrient Requirements of Beef Cattle. 6th Ed. National Academy of Science, Washington, DC, USA.
National Research Council (NRC). 2001. Nutrient Requirements of Dairy Cattle. 7th Ed. National Academy of Science, Washington, DC, USA.

Negi, S. S., B. Singh, and H. P. S. Makkar. 1988. An approach to the determination of rumen degradability of nitrogen in lowgrade roughages and partition of nitrogen therein. J. Agric. Sci. (Camb.) 111:487-493.

Prestløkken, E. and O. Rise. 2003. Protein and amino acid digestibility in dairy cows measured with mobile nylon bags recovered in ileum or in faeces. Acta. Agric. Scand. Section A. Anim. Sci. 53:11-20.

Qun, Y., H. J. Yang, and C. Y. Xie. 2007. Evaluation of small intestinal digestibility in protein of common feed in ruminant using mobile nylon bag method and three step in vitro method. J. China Agric. Univ. 12(6): 62- 66.

Taghizadeh, A., M.D. Mesgaran and R.Valizadeh. 2005. Digestion of feed amino acids in the rumen and intestine of steers measured using a mobile nylon bag technique. J. Dairy Sci. 88: 1807- 1814.

Webster, A. J. F., M. A. Kitcherside, J. R. Keirby, and P. A. Hall. 1984. Hall Evaluation of protein feeds for dairy cows. J. Anim. Prod. 8:548-553.

Van Soest, P. J., J. B. Robertson, and B. A. Lewis. 1991. Methods for dietary fiber, neutral detergent fiber, and nonstarch polysaccharides in relation to animal nutrition. J. Dairy Sci. 74:3583-3597.

SAS. 1999. User's Guide: Statistics, 8th Ed. SAS Institute. Inc, Cary NC, USA

Van Straalen, W. M. and S. Tamminga. 1990. In: Feedstuffs Evaluation (Eds. J. Wiseman and D. J. A. Cole). Buttenvorths, London, UK. pp. 55-59.

Van Straalen, W. M., J. J. Odiga, and W. Mostert. 1997. Digestion of feed amino acids in the rumen and small intestine of dairy cows measured with nylon-bag techniques. Br. J. Nutr. 77:8397.

Voigt, J., B. Piatkowski, H. Engelmann, and E. Rudolph. 1985. Measurement of the postruminal digestibility of crude protein by the bag technique in cows. Arch. Tierernaahr. Berlin. 35:555-562.

Van Straalen, W. M., F. M. H. Dooper, A. M. Antoniewicz, I. Kosmala, and A. M. vanVurren. 1993. Intestinal digestibility in dairy cows of protein from grass and clover measured with mobile nylon bag and other methods. J. Dairy Sci. 76:29702981.

Stern, M. D., A. Bach, and S. Calsamiglia. 1997. Alternative techniques for measuring nutrient digestion in ruminants. J. Anim. Sci. 75:2256-2276.

Varvikko, T. and A. Vanhatalo. 1991. Intestinal nitrogen of hay and grass silage estimated by the mobile nylon bag technique. World Rev. Anim. Prod. 16: 73-76.

Von Keyserlingk, M. A. G., M. L. Swiftb, and A. R. Puchalac. 1996. Degradability characteristics of dry matter and crude protein of forages in ruminants. Anim. Feed Sci. Technol. 57: 291-311.

Woods, V. B., A. P. Moloney, S. Calsamiglia, F. P. O’Mara. 2003. The nutritive value of concentrate feedstuffs for ruminant animals: Part III. Small intestinal digestibility as measured by in vitro or mobile bag techniques. Anim. Feed Sci. Technol. 110:145-157. 